\title{
THE CONCEPTION OF TIME IN SHAKESPEARE'S SONNETS
}

\section{Lidia da Cruz Cordeiro Moreira ${ }^{1}$}

\begin{abstract}
Time is the main theme in twenty-two of William Shakespeare's 126 sonnets dedicated to the Fair Youth, although its presence can be felt throughout the entire sequence. This article will investigate how the bard's concern with Time may have been influenced by the thought of his age, and will analyse some of these twenty-two sonnets in which Time is a main issue.

Key Words: Shakespeare's Sonnets, Time, Renaissance.
\end{abstract}

Resumo: 0 Tempo é o tema principal em vinte e dois dos 126 sonetos de William Shakespeare dedicados ao Fair Youth, embora sua presença possa ser sentida ao longo de toda a seqüência. Este artigo investigará como o interesse do bardo na questão do Tempo pode ter sido influenciada pelo pensamento de sua época e analisará alguns desses vinte e dois sonetos nos quais o Tempo é a principal preocupação.

Palavras-Chave: Sonetos de Shakespeare, Tempo, Renascimento.

\section{INTRODUCTION}

Despis'd, distressed, hated, martyr'd, kill'd, Uncomfortable time, why cam'st thou now

To murther, murther our solemnity? (Romeo \& Juliet, Act IV, Scene 5).

Much has been written about Shakespeare's universalism, since his contemporary Ben Jonson's eulogy prefixed to the First Folio Edition of Shakespeare's Plays in 1623 which states that the bard "was not of an age, but for all time" (JONSON, 2007, n/d) until our days when Shakespeare's universalism is praised by authors such as Harold Bloom who affirms that though "[u]niversalism is now not much in fashion [...] [y]et I hardly see how one can begin to consider Shakespeare without finding some way to account for his pervasive presence in the most unlikely contexts: here, there, and everywhere at once" (BLOOM, 1998, p. 3).

Nevertheless, however universal an author Shakespeare might be considered, he was in fact a man of his time, and his work is permeated by the ideas and beliefs of his age, an age of deep changes in thought brought about not only by the Renaissance's new Humanism but also by the new scientific discoveries and the discovery of the New World. One of these innumerable shifts

1 Mestranda em Letras, área de concentração: Literaturas de Língua Inglesa, no Programa de Pós-Graduação em Letras da Universidade do Estado do Rio de Janeiro - PPGLET/UERJ. Endereço eletrônico: lidccm@gmail.com. 
was the change in the human conception of time, both in theory and in the way it was lived and experienced, which explains Shakespeare's immense interest in the theme of time and the numerous references to it in his work. In this paper I will describe the major changes in the conception of time in the passage from the Middle Ages to Modernity and their reflections in Shakespeare's Sonnets.

\section{THE NEW CONCEPTION OF TIME IN MODERNITY}

Had Shakespeare been a medieval writer, time would probably not have been a major concern to him. Or, at least, it would have been treated in totally different terms. But in Elizabethan England it had already become an obsession, which can be explained by the developments in clock-making. Until the end of the Middle Ages, mechanical clocks were very rudimentary, imprecise objects, even less precise than some clepsydras (water clocks). They did not indicate the subdivisions of the hour and even the hours themselves were indicated with some margin of error, which made them quite useless objects. Furthermore, they were huge objects, difficult to maintain and very costly, which consequently made them extremely rare, only present in wealthy cities, kings' palaces or abbeys and cathedrals.

Nevertheless, though the medieval man did not know precisely what time it was, he knew it was time to do this or that activity according basically to two elements: nature and the church bells. As French philosopher Alexandre Koyré affirms about medieval society:

It does not feel a great need to know the hours. It perpetuates, as L. Febvre affirms so well, "the habits of a society of farmers who accept never knowing the exact hour, unless the bell tolls (supposing it is correct) and for the rest they resource to plants, animals, the flight of this bird or the singing of that other". "Around sunrise" or "around sunset".

Daily life is dominated by natural phenomena, by sunrise and sunset - people wake up early and do not go to bed late - and the day is more divided than it is measured by the tolling of the bell which announce "the hours" - the hours of religious offices, not those of the clock (KOYRÉ, 1991, p. 281 - my translation from the version in Portuguese).

In short, time in the Middle Ages was both natural and ecclesiastical, it obeyed both the rhythm of the seasons and that of church bells. It was not measured, but it was lived and daily life moved in the "more-or-less" of lived time and not in the precision of measured time.

However, throughout the $\mathrm{XV}{ }^{\text {th }}$ century clock-making saw great progress, which would only culminate in the middle of the following century. Clocks became more compact and, though still expensive, they were not so rare any- 
more. More importantly, they became much more precise. For instance, clocks with minute hands started to be used, and although this sounds highly imprecise for today's patterns, compared to the total imprecision of medieval times, it meant indeed a revolution in the lives of common men, as clocks invaded homes and workshops and started dictating the rhythm of domestic affairs and labour.

Thus, men no longer depended on nature to tell them what time it was and, in fact, it is no coincidence that the dissemination of clocks was parallel to the growth of towns and the substitution of town life for country life. Likewise, men did not depend on church bells to keep time anymore and it is also no coincidence that the improvements in clock-making are deeply related to the rise of Protestantism. Although the birth of clock-making took place in Italy, it was in Protestant countries like England where it flourished. Measuring time is an act that is much more consonant with the protestant than with the catholic faith. As the wasting of time was seen as godlessness, a good Protestant's routine should be similar to a clock and no hour should be wasted.

The Protestant Reformation was also more consonant with the new conceptions brought about by the Scientific Revolution started in 1543, as it promoted an atmosphere of tolerance to new ideas. As Copernicus argued that not the Earth but the Sun was the centre of the universe, man's sense of himself and of the world was also dislocated. Moreover, still in the XVI ${ }^{\text {th }}$ century, Giordano Bruno's beliefs in the infinity of the universe and a plurality of worlds also contributed to the prevailing feeling of uncertainty. John Donne's words in his Anatomy of the World, published in 1611, provide a very good picture of this prevalent feeling:

And new philosophy calls all in doubt,

The element of fire is quite put out,

The sun is lost, and th'earth, and no man's wit

Can well direct him where to look for it.

And freely men confess that this world's spent,

When in the planets and the firmament

They seek so many new; they see that this

Is crumbled out again to his atomies.

'Tis all in pieces, all coherence gone (DONNE, 2007, p. n/d).

Geocentricism and anthropocentricity were challenged and the wellenclosed Ptolemaic universe where permanence reigned was replaced by an unfamiliar universe marked by corruption and mutability, where "all coherence [was] gone". This uncertainty was in turn responsible for a sense of pessimism also widespread at the time. As John Kerrigan affirms in his introduction to The Sonnets and a Lover's Complaint, "every clock declared that an hour of life, 
considered another way, was an exact, irretrievable hour nearer death" (KERRIGAN, 1995, p. 35). As a reminder of the inexorability of time, many watches at Shakespeare's time bore some symbol of death or moral saying.

\section{TIME IN SHAKESPEARE'S SONNETS}

It is this conception of time as inexorable that is prevailing in Shakespeare's sonnets or, more precisely, in the 126 first poems - the Fair Youth sequence - in which there are 70 occurrences of the word time, whereas in the subsequent 26 poems dedicated to the Dark Lady and in the two final allegoric poems the word does not occur at all. This is explained by the fact that underlying the theme of time is the poet's worry about its effects over the Youth's beauty, which is not a concern in the Dark Lady sequence.

\subsection{THE PROCREATION GROUP — SONNETS 5 AND 12}

Although the main theme in the first 17 sonnets is that of procreation, anxiety over time already looms over these poems. In sonnet 5, time is referred to as a tyrant, as in the first quatrain the poet laments its passing and its effects over the Youth's beauty. The hours - that is, time - that made the Youth beautiful in his young days will make him ugly as he grows old:

Those hours, that with gentle work did frame

The lovely gaze where every eye doth dwell,

Will play the tyrants to the very same

And that unfair which fairly doth excel;

In the second quatrain, the poet accentuates time's tyranny as he calls it "never-resting" and moves on to compare the progress of human life to that of the seasons, from summer to "hideous winter" characterized by "bareness every where":

For never-resting time leads summer on

To hideous winter, and confounds him there;

Sap checked with frost, and lusty leaves quite gone,

Beauty o'er-snowed and bareness every where:

Finally in the last quatrain and in the couplet, the poet reminds the youth that summer's beauty only remains in the essence of flowers distilled to be used as perfume, thus implying that the Youth should procreate so that his beauty may survive:

Then were not summer's distillation left,

A liquid prisoner pent in walls of glass,

Beauty's effect with beauty were bereft,

Nor it, nor no remembrance what it was: 
But flowers distill'd, though they with winter meet,

Leese but their show; their substance still lives sweet.

In sonnet 12, one of the most well-known sonnets, the poet returns to the description of the effects of time over nature and the defence of procreation as the only way of standing against time. In the first two lines, the poet refers to the transformation of day into night, here qualified as "hideous" the same adjective used to describe winter in sonnet 5 , line 6 :

When I do count the clock that tells the time,

And see the brave day sunk in hideous night;

The first line itself already shows man's powerlessness when facing time, as the poet affirms that the clock tells the time and all he can do is "count the clock", that is, man does not count the time, the clock does. The clock is the inexorable mediator between man and time and man has no power over any of them. The mechanical rhythm of the line - marked by the alliteration of $/ \mathrm{k} /$ in "count" and "clock" and / $t$ / in "tells" and "time" - reminds us of the ticking of a clock and, in fact, the rhythm of the whole poem does the same, as the sense of each line ends within the line itself. In the next 6 lines, the poet moves on to describing the inescapable transformation of summer into winter, turning beautiful things into lifeless ones:

When I behold the violet past prime,

And sable curls, all silvered o'er with white;

When lofty trees I see barren of leaves,

Which erst from heat did canopy the herd,

And summer's green all girded up in sheaves,

Borne on the bier with white and bristly beard,

In the last quatrain, the poet then questions the permanence of the Youth's beauty, since, like all sweet and beautiful things, he too shall decay and eventually die by the action of time:

Then of thy beauty do I question make,

That thou among the wastes of time must go,

Since sweets and beauties do themselves forsake

And die as fast as they see others grow;

This last line points to the continuous mutability of things, one of the signs of time's inexorable passage. Finally, in the couplet, the poet will once more defend procreation as the only defence against time's action, but this time he is more explicit than in sonnet 5, in which it is only insinuated:

And nothing 'gainst Time's scythe can make defence

Save breed, to brave him when he takes thee hence. 
In the last three sonnets known as "procreation sonnets" (15-17), however, the poet will little by little assert another way of resisting time, which is through poetry, although this idea will only be fully affirmed in sonnets 18 and 19. In the first two lines of sonnet 15, the poet's anxiety over the effects of time is clear in his affirmation that all growing things have only a moment of perfection:

When I consider every thing that grows

Holds in perfection but a little moment,

In the next line, the poet refers to the world as a stage, which is a recurrent comparison in Shakespeare's work and emphasizes the transience of life which "presenteth nought but shows", that is, which is only illusory:

That this huge stage presenteth nought but shows

Moreover, man's powerlessness is stressed by the next line which states that the stars watch man on this stage and decide upon his fate:

Whereon the stars in secret influence comment;

According to W. R. Elton, "Shakespeare's era topically and repeatedly figured the world as stage, and man as actor in temporary and borrowed costume, strutting and fretting his meaningless hour" (ELTON, 1997: 32). In the next quatrain, the poet once again compares the decline of man to that of nature until they are worn out and totally forgotten:

When I perceive that men as plants increase,

Cheered and checked even by the self-same sky,

Vaunt in their youthful sap, at height decrease,

And wear their brave state out of memory;

In the third quatrain the poet addresses the Youth, telling him that this thought brings the Youth's image to the poet's sight, but he still cannot resist the action of Time and Decay - here personified - who will destroy his beauty, turning it into "sullied night".

Then the conceit of this inconstant stay

Sets you most rich in youth before my sight,

Where wasteful Time debateth with Decay

To change your day of youth to sullied night,

By referring to the Youth's beauty as his "day of youth" in the singular form, as if he was referring to one single day in which the Youth's beauty was most perfect, the poet goes back to line 2 , in which he had affirmed that all 
growing things have one single moment of perfection. Finally, in the couplet the poet states that, despite all the world's fight against Time to save the Youth, it is only through his verse that he can be immortalized:

And all in war with Time for love of you,

As he takes from you, I engraft you new.

In 16 and 17, the poet goes back to the theme of procreation absent in 15 and confronts it with verse-immortality, still affirming the former as superior to the latter. Sonnet 16 starts, in fact, as an immediate continuation to 15 , marked by the word "but", asking the Youth to fight Time - once more described as a tyrant - in a more powerful way than the poet can fight through his verse:

But wherefore do not you a mightier way

Make war upon this bloody tyrant, Time?

And fortify your self in your decay

With means more blessed than my barren rhyme?

This more powerful alternative is procreation, as is seen in the second quatrain, when the poet suggests that many unmarried girls would gladly bear the Youth's children, who would be much more similar to him than the poet's verse could be:

Now stand you on the top of happy hours,

And many maiden gardens, yet unset,

With virtuous wish would bear you living flowers,

Much liker than your painted counterfeit:

The third quatrain reaffirms the idea that no verse could reproduce the Youth to the eyes of other men better than his own offspring:

So should the lines of life that life repair, Which this, time's pencil or my pupil pen, Neither in inward worth nor outward fair,

Can make you live your self in eyes of men.

Therefore, in the couplet, the poet urges the Youth to give himself away in marriage, so that he can preserve himself forever, that is, against time's decay, by his own art:

To give away yourself, keeps yourself still,

And you must live, drawn by your own sweet skill.

Sonnet 17, the final "procreation sonnet", continues the ideas already developed in 16 but adds the notion that future men would not believe such 
beauty as the Youth's to be possible in an earthly creature, even though the poet judges himself incapable of fully reproducing it:

\author{
Who will believe my verse in time to come, \\ If it were fill'd with your most high deserts? \\ Though yet heaven knows it is but as a tomb \\ Which hides your life, and shows not half your parts. \\ If I could write the beauty of your eyes, \\ And in fresh numbers number all your graces, \\ The age to come would say 'This poet lies; \\ Such heavenly touches ne'er touch'd earthly faces.'
}

The poet goes on in the third quatrain saying that his poetry would be mocked as a babbling old man and that the Youth's beauty would be considered the mad inspiration of a poet or the hyperbolic verse of old times:

So should my papers, yellow'd with their age,

Be scorn'd, like old men of less truth than tongue,

And your true rights be term'd a poet's rage

And stretched metre of an antique song:

Finally, in the couplet is the final urging to the Youth to procreate, though here it is counterbalanced by verse as another means to achieve immortality:

But were some child of yours alive that time,

You should live twice, in it, and in my rhyme.

2.3 The AfFIRM ATION OF IM M ORTALITY-THROUGH-VERSE - SONNETS 18, 19, 55 AND 60

In 18 and 19 the procreation theme is finally fully abandoned by the poet and immortality-through-verse is affirmed as the sole remedy against time. In the first two quatrains of 18 , the poet states the Youth is more lovely and temperate than a summer's day:

Shall I compare thee to a summer's day?

Thou art more lovely and more temperate:

Then, in lines 3 to 6 the poet proceeds to describe the excesses a summer's day may bring, such as violent winds and excessive heat, besides the fact that summer is too short and the sun might be covered by clouds:

Rough winds do shake the darling buds of May,

And summer's lease hath all too short a date:

Sometime too hot the eye of heaven shines,

And often is his gold complexion dimmed, 
The poet ends the second quatrain by concluding that all beauty eventually becomes less beautiful, accidentally or by the action of time:

And every fair from fair sometime declines,

By chance, or nature's changing course untrimmed:

However, the Youth's beauty shall never end as he will be eternalized by the poet in his verse, granting him immortality:

But thy eternal summer shall not fade,

Nor lose possession of that fair thou ow'st,

Nor shall death brag thou wander'st in his shade,

When in eternal lines to time thou grow'st,

This last idea is reinforced by the celebrated couplet which affirms that as long as there are men living, the poet's verse will live too and allow the Youth's beauty to live in it:

So long as men can breathe, or eyes can see,

So long lives this, and this gives life to thee.

Sonnet 19 basically deals with the same concepts as 18, though the images the poet now uses in the first quatrain to describe the decay time causes in nature are more violent. Time destroys even the fiercest creatures - the lion, the tiger - or creatures mythically considered immortal as the phoenix. Moreover, all creatures return to the earth of which they are made:

Devouring Time, blunt thou the lion's paws,

And make the earth devour her own sweet brood;

Pluck the keen teeth from the fierce tiger's jaws,

And burn the long-lived phoenix in her blood;

In the second quatrain, in line 5 the poet once more resorts to the seasons of the year to illustrate the action of time, which alternates happy (summer, spring and autumn, though the latter had an ambiguous state) and unhappy (winter) seasons as it passes. The poet then admits in lines 6 and 7 that "swift-footed Time" is uncontrollable and can do whatever it wants to the whole world and its beautiful things:

Make glad and sorry seasons as thou fleet'st,

And do whate'er thou wilt, swift-footed Time,

To the wide world and all her fading sweets;

However, in the last line in the second quatrain and all through the third, the poet still attempts to defy the inexorability of time by prohibiting it from acting over the Youth's beauty, which should be preserved as a model for future men: 
But I forbid thee one most heinous crime:

0 ! carve not with thy hours my love's fair brow,

Nor draw no lines there with thine antique pen;

Him in thy course untainted do allow

For beauty's pattern to succeeding men.

Although in the couplet the poet finally forsakes his prohibition, admitting that time cannot be stopped, immortality-though-verse is once again reaffirmed as the only remedy against time:

Yet, do thy worst old Time: despite thy wrong,

My love shall in my verse ever live young.

From sonnets 20 to 53, the theme of time and immortality-throughverse does not appear until the poet returns to it in 54 and 55, although in 54 it is simply alluded to in the final couplet, as the main theme of the sonnet is the relationship between inner and outward beauty. Sonnet 55 , however, returns to the theme resounded in the previous sonnet as its main theme. The poet states that no monument made of marble or stone, not even those of the royalty, shall live longer or "shine more bright" than his verse and the Youth in it pictured:

Not marble, nor the gilded monuments

Of princes, shall outlive this powerful rhyme;

But you shall shine more bright in these contents

Than unswept stone, besmear'd with sluttish time.

The adjective "sluttish" is here used for the first time to modify the word "time". It Shakespeare's age, it used to be applied to both men and women who had dirty habits and behaviour, and, in relation to time, it describes its lack of interest in keeping the world tidy. In the second quatrain, the poet reasserts the immortality of the Youth, or at least of its written record, as it will survive all wars which destroy statues and buildings. Not even Mars - the God of War - will be able to destroy it:

When wasteful war shall statues overturn,

And broils root out the work of masonry,

Nor Mars his sword, nor war's quick fire shall burn

The living record of your memory.

The last quatrain and the couplet reaffirm once again this idea, with some biblical echoes in "to the ending doom" and "till the judgment", meaning until the end of time:

'Gainst death, and all oblivious enmity

Shall you pace forth; your praise shall still find room

Even in the eyes of all posterity 
That wear this world out to the ending doom.

So, till the judgment that yourself arise,

You live in this, and dwell in lovers' eyes.

After a brief interval, the themes of the destruction caused by time and that of immortality-through-verse emerge again in 60 . In this sonnet, the poet compares the unstoppable movement of the waves reaching the shore to the passing of time, "our minutes". As mentioned before, clocks and watches with minute hands only appeared in Shakespeare's age and when he wanted to refer to the smallest portions of time, he used "minutes" and not "seconds", a word that would only appear later:

Like as the waves make towards the pebbled shore,

So do our minutes hasten to their end;

Each changing place with that which goes before,

In sequent toil all forwards do contend.

The poet proceeds in the two following quatrains to describe the effects of time from birth to maturity, when "crooked eclipses" (meaning "setbacks") fight against the glory of youth, which time eventually destroys, by wrinkling it. Time is again portrayed as carrying a scythe, an image very common at the time:

Nativity, once in the main of light,

Crawls to maturity, wherewith being crown'd,

Crooked eclipses 'gainst his glory fight,

And Time that gave doth now his gift confound.

Time doth transfix the flourish set on youth

And delves the parallels in beauty's brow,

Feeds on the rarities of nature's truth,

And nothing stands but for his scythe to mow:

The couplet, however, asserts once again that the poet's verse is the only antidote against time:

And yet to times in hope, my verse shall stand

Praising thy worth, despite his cruel hand.

\subsection{DOUBTING IM M ORTAUTY-THROUGH-VERSE — SONNETS 63 TO 65 AND 71 TO 74}

The themes of time and immortality reappear in 63 to 65 . Since sonnet 63 presents very few variations in relation to how the themes have been developed in previous and later sonnets, it will not be necessary to analyze it here. The same applies to sonnet 64 , although the latter has at least one peculiarity in relation to the others, which is the fact that it does not present the poet's verse as a remedy against time's destruction, but states in the final 
couplet that crying is the only thing the poet can do when confronted with the thought of the decay and death of the Youth:

This thought is as a death which cannot choose

But weep to have that which it fears to lose.

In 65, however, immortality-through-verse appears again, though the poet sounds much less assured of its possibility. He starts by comparing the frailty of the Youth's beauty, which is as strong as a flower, to resistant (brass, stone, earth) and limitless (sea) elements. Since none of these can defy mortality, the poet questions how the Youth's beauty could possibly do it:

Since brass, nor stone, nor earth, nor boundless sea,

But sad mortality o'ersways their power,

How with this rage shall beauty hold a plea,

Whose action is no stronger than a flower?

This idea is only reinforced in the second quatrain, in which the Youth's beauty is described as "summer's honey breath" and compared to rocks and gates of steel the same way it was compared to other elements in the first quatrain. Once again the poet poses a question that he leaves unanswered:

O! how shall summer's honey breath hold out,

Against the wrackful siege of battering days,

When rocks impregnable are not so stout,

Nor gates of steel so strong but Time decays?

In the third quatrain, the poet poses a series of three more questions which he will only answer in the couplet. In fact, all these questions and the previous ones are the same: how can the Youth's beauty survive time?

0 fearful meditation! where, alack,

Shall Time's best jewel from Time's chest lie hid?

Or what strong hand can hold his swift foot back?

Or who his spoil of beauty can forbid?

In the couplet the poet answers his questions by once more affirming that poetry is the only answer to time's destruction. Nevertheless, he refers to it as a miracle, one whose power he is not sure of:

0 ! none, unless this miracle have might,

That in black ink my love may still shine bright.

In fact, the whole poem sounds much less assured of the power of verse to bestow immortality than the ones before, such as the assertive 18 and the challenging 19. This insecurity and desperation is reinforced by the interrogations in lines 4, 8, 10, 11, 12 and by the exclamations starting lines 5, 9 and 13. 
This desolate tone will be used again in sonnets 71 to 74 , in which the poet will once again deal with the theme of time, though now immortalitythrough-verse will not be defended, only suggested in 74 . The four poems are considerations on human aging and mortality and speculate on the memory the Youth will keep of the poet after his death. In short, throughout 71 and 72 , the poet tells the Youth not to mourn him but for a short period and not to think of him after his death if this makes the Youth sad. Sonnet 73 describes the action of time over living things as it was done in previous sonnets. However, what is peculiar about it is the way the poet relates the passing of time, shortening its scope from quatrain to quatrain. In the first quatrain, the poet compares human life to a year and himself to autumn, the season of the year when few yellow leaves hang upon the bare boughs of trees - where not long before birds sang - announcing the proximity of the winter, a metaphor for old age:

That time of year thou mayst in me behold

When yellow leaves, or none, or few, do hang

Upon those boughs which shake against the cold,

Bare ruined choirs, where late the sweet birds sang.

In the second quatrain, the poet reduces the time span he compares to human life from a year to a day and compares himself to the twilight, the time of day which announces the darkness of night (which represents old age) and sleep (representing death):

In me thou see'st the twilight of such day

As after sunset fadeth in the west;

Which by and by black night doth take away,

Death's second self, that seals up all in rest.

In the third quatrain, the poet condenses the duration of time to that of a fire and compares himself to a fire that does not burn at its height any more:

In me thou see'st the glowing of such fire,

That on the ashes of his youth doth lie,

As the death-bed, whereon it must expire,

Consumed with that which it was nourish'd by.

All in all, the compression of the time span described from the first to the third quatrain only reinforces the sense of brevity of life conveyed in the sonnet. In the couplet, the poet concludes that, by perceiving that which he has described, the Youth will love him even more for knowing that he will not be around for much longer. It could also imply that the Youth would love himself or his own life more for knowing that also his youth and beauty will not last forever: 
This thou perceiv'st, which makes thy love more strong,

To love that well, which thou must leave ere long.

Closing the quartet of sonnets is 74, in which the poet tells the Youth that even when his body is dead, his spirit - the best part of him - will survive in his verse. In a way, the poem presents a variation of the theme of immortality-through-verse, since here the poet states the immortality of his own spirit in his verse and not that of his object, the Youth, as in the other sonnets which deal with this theme. However, the poet does not claim his verse will be immortal for all future men to read, but only for the Youth.

\subsection{IMM MRTALITY V. ANONYMITY — SONNET 81}

The worry about time's destruction and mortality will reappear in sonnet 81, together with the theme of immortality-through-verse, though the word "time" is actually not used in the poem. Nevertheless, although the poet had reserved some dose of immortality to himself in 74, now he claims that only the Youth will be immortal through his poetry, whereas he will be totally forgotten once his body is dead. In the first quatrain, the poet tells the Youth that regardless who dies first, the Youth will be remembered whereas the poet will be totally forgotten:

Or I shall live your epitaph to make,

Or you survive when I in earth am rotten,

From hence your memory death cannot take,

Although in me each part will be forgotten.

In the second and third quatrains and the couplet, the poet tells the Youth his name will be immortalized in his verse for future men to see and speak, though that of the poet will be dead. The verse will be like an elaborate grave to the Youth, whereas the poet will have only an ordinary grave:

Your name from hence immortal life shall have,

Though I, once gone, to all the world must die:

The earth can yield me but a common grave,

When you entombed in men's eyes shall lie.

Your monument shall be my gentle verse,

Which eyes not yet created shall o'er-read;

And tongues to be, your being shall rehearse,

When all the breathers of this world are dead;

You still shall live, such virtue hath my pen,

Where breath most breathes, even in the mouths of men.

It is highly ironic that the poet affirms the Youth's name will be immortal, since it is never mentioned and the readers, the "eyes not yet created" and "tongues to be", will never be able to be totally certain about who the Youth 
really was. If Shakespeare did not reveal the name of his beloved Fair Youth intentionally or not is also not known, but what is certain is that the immortal name of the Youth will never be known to future men.

\subsection{THE EFFECTS OF TIM E OVER LOVE — SONNETS 115 AND 123 TO 126}

In sonnet 115, the poet returns to the subject of time, now to marvel at the action of time over love. He starts by stating that all the sonnets written before this one were lying, especially those that said he could never love the Youth more than he already did then, because his love is now stronger than ever:

Those lines that I before have writ do lie,

Even those that said I could not love you dearer:

Yet then my judgment knew no reason why

My most full flame should afterwards burn clearer.

In the second quatrain, the poet describes time as "reckoning" - meaning time calls all things to account - and full of accidents. He then enumerates the bad effects of time over beautiful and strong things: it disturbs sacred vows, annuls the orders of kings, destroys beauty, dulls the keenest purposes and changes strong minds:

But reckoning Time, whose million'd accidents

Creep in 'twixt vows, and change decrees of kings,

Tan sacred beauty, blunt the sharp'st intents,

Divert strong minds to the course of altering things;

In the third quatrain, the poet refers to time once again as a tyrant, as he had done in 5 and 16. Fearing the effects of time described above and being certain of the extent of his love at the moment he wrote his previous sonnets, he wonders why he could not "crown the present" and doubt the future, therefore saying that he could never love the Youth more:

Alas! why, fearing of Time's tyranny,

Might I not then say, 'Now I love you best,'

When I was certain o'er incertainty,

Crowning the present, doubting of the rest?

The couplet brings the answer to the question: no, he could not say 'Now I love you best' and affirm his love to the full, since love is a babe - in a reference to Cupid - and, therefore, is always growing:

Love is a babe, then might I not say so,

To give full growth to that which still doth grow? 
As the end of the Fair Youth sequence approaches, in 123 to 125, the poet insists that his love for the Youth is unchangeable and immortal, not subject to time's destruction. In 123, the poet addresses Time and defies it by vowing to be true to his love despite time's action. In 124 and 125, he states his love for the Youth is not like those who depend on the approval of conventions or politics, a kind of love which he calls "time's fool". What is interesting to note in these three sonnets is the pattern by which a quatrain in each sonnet starts with the exclamation 'No!' - the first quatrain in 123, the second in 124 and the third in 125 - as a way of emphasizing that act of defiance against time started in 123. This leads to the speculation that the couplet in 126 should also start the same way. However, sonnet 126 is an anomaly in form, since it is written in six rhyming couplets, having thus only 12 verses and no final couplet. There is no agreement upon whether it was omitted on purpose at the time of the publication of the sonnets or if it was never in fact written. Thematically, though, the sonnet returns to most themes already treated before, including that of time's inexorable destruction, but not that of immortality-through-verse. In the first two couplets, the poet affirms that the Youth, although getting old, is not decaying the same way his lovers are, which only makes their decay more noticeable:

\footnotetext{
0 thou, my lovely boy, who in thy power

Dost hold Time's fickle glass, his sickle, hour;

Who hast by waning grown, and therein showest

Thy lovers withering, as thy sweet self growest.
}

In the third and fourth couplets, the poet explains that this occurs because Nature has been saving the Youth from the ravages of Time, in order to beat it:

If Nature, sovereign mistress over wrack,

As thou goest onwards still will pluck thee back,

She keeps thee to this purpose, that her skill

May time disgrace and wretched minutes kill.

Nevertheless, although Nature is 'sovereign mistress over wrack', she is not sovereign mistress over Time, that is, she cannot reverse Time's action but only decide when it will take place. Therefore, in the last two couplets, the poet tells the Youth that Nature cannot save him forever. When she finally has to settle her account with Time for keeping the Youth for so long, she will have to sacrifice him in order to pay her debt:

Yet fear her, 0 thou minion of her pleasure!

She may detain, but not still keep, her treasure: 
Her audit (though delayed) answered must be,

And her quietus is to render thee.

As mentioned before, this farewell sonnet to the Youth does not defend the idea that he will be immortalized through verse. The reader is left with the feeling that, after all, not even the Youth can escape from Time. As John Kerrigan states in the conclusion to his Introduction to The Sonnets and A Lover's Complaint,

[b]eauty cannot save him, nor all the poet's labours, which strive to make the friend a 'god', and try to recoup, by recounting, the clock. In Shakespeare's Sonnets, at the last, Time circumscribes the natural world and the very springs of life, while verse can only make memorial, inscribing what, without art, would always already be gone (KERRIGAN, 1997, p. 63).

Nevertheless, the explanation for the absence of the final defence of immortality-through-verse might also reside in the absence of the final couplet. It has been speculated whether Thomas Thorpe, the original publisher of the sonnets, excluded the couplet, which might have made an explicit reference to the identity of the Fair Youth. It has also been speculated, on the other hand, that the absence was designed by the poet, as part of the negation pattern explained above, as the final negation against time, which could be better achieved through silence than through words.

\section{CONCLUSION}

Time is the main theme in at least twenty-two of the sonnets dedicated to the Fair Youth, though its presence looms over the whole sequence. This reflects Shakespeare's personal concerns about human mortality and the inexorability of time's devastating effects over man's life. These concerns, in turn, reflect a general anxiety of Shakespeare's age, in the wake of M odernity, when time shifted from its medieval conception of a lived experience to a measured element of man's life.

However, regardless how worried Shakespeare was about his own mortality and disappearance from this world, his poetry has indeed survived and will probably survive 'so long as man can breathe'. It is, nevertheless, profoundly ironic that the poet never really advocated his own immortality but only that of his object, the Youth, since readers nowadays have no knowledge of the identity of the Youth, whereas the name of Shakespeare is probably the most well-known name in the literature of his age and 'for all time'. 


\section{REFERENCES}

BLOOM , Harold. Shakespeare's Universalism. In: Shakespeare: The Invention of the Human. New York: Riverhead Books, 1998, p. 1-17.

DONNE, John. An Anatomy of the World (excerpt). In: Representative Poetry Online. Disponível em: «ttp://rpo.library.utoronto.ca/ poem/643.html>. Acesso em: 6 ago. 2007.

ELTON, W. R. Shakespeare and the Thought of His Age. In: WELS, Stanley. (Ed.). The Cambridge Companion to Shakespeare Studies. Cambridge: CUP, 1997, p. 17-34.

JONSON, Ben. To the Memory of My Beloved the Author, Mr. William Shakespear. In: Representative Poetry Online. Disponível em: বttp://rpo.library.utoronto.ca/poem/1117.html>. Acesso em: 6 ago. 2007.

KERRIGAN, John. Introduction. In: SHAKESPEARE, William. The Sonnets and A Lover's Complaint. Harmondsworth: Penguin, 1995, p. 7-63.

KOYRÉ, Alexandre. Do mundo do 'Mais-Ou-Menos' ao universo da precisão. In: Estudos de história do pensamento filosófico. Trad. Maria de Lourdes Menezes. Rio de Janeiro: Forense Univeritária, 1991, p. 271-288.

LEDGER, G. R. Shakespeare's Sonnets. Disponível em: «ttp://www.shakespearessonnets.com/index.htm>. Acesso em: 6 ago. 2007.

ROSENFELD, Anatol. Shakespeare e o pensamento renascentista. In: Texto/Contexto. São Paulo: Perspectiva, 1976, p. 123-145.

SHAKESPEARE, William. Os sonetos completos. Trad. Vasco Graça Moura. São Paulo: Landmark, 2005.

SHAKESPEARE, William. The Sonnets. Cambridge: CUP, 1996. 